\title{
A veszélyeztetett vadon élö fajok szállításának vámhatósági ellenőrzése
}

\section{HARNBERGER György ${ }^{1}$ - ZSIGMOND Csaba²}

„A Föld nem a tulajdonunk, csak hozzá tartozunk. Muszáj megosztanunk a vadvilággal"’3

(Steve Irwin 1962-2006)

\begin{abstract}
A veszélyeztetett állat- és növényfajok legális és illegális kereskedelmének következtében a világon évente több ezer újabb faj fennmaradása kerül veszélybe, ennek ellenére sem nemzetközi, sem hazai szinten e tevékenységek nem kapnak kellö figyelmet sem a hatóságok, sem a közvélemény részéről. Jelen cikkben a szerző́k a legális és illegális kereskedelem jellemzőit, jogi hátterét, illetve a vámhatósági ellenőrzések elméleti hátterét, gyakorlati tapasztalatait vizsgálták meg. A téma elméleti bemutatása érdekében áttekintést nyújtanak a vonatkozó nemzetközi és hazai jogszabályokról, illetve a nemzetközi szakirodalom segítségével bemutatják annak nemzetközi tendenciáit. A Nemzeti Adó- és Vámhivatal Központi Irányítása által kezelt lefoglalási adatok elemzése, illetve szakértői interjúk segítségével vizsgálták meg az illegális kereskedelem jellemzőit. Megállapították, hogy bár hazánk nem tölt be központi szerepet a veszélyeztett fajok legális és illegális kereskedelmében, azonban mind a legális, mind az illegális kereskedelem értéke éves szinten több száz millió forintot ér el. Az illegális kereskedelemben hazánk leginkább tranzitszerepet tölt be, és jellemzően elsősorban légi úton valósul meg. A lefoglalási adatok arról tanúskodnak, hogy a csempészetet sok esetben nagyobb tételben követik el, amely mögött vélhetöen nemzetközi csempészhálózatok, szervezetek állhatnak. Az interjúk során elhangzott, hogy a lefoglalások csupán töredékei lehetnek a valós forgalomnak, mivel nagyfokú a látencia. A cikk és az elvégzett kutatás eredményei alapján kijelenthetó, hogy a téma nagyobb prioritást érdemel, valamint az illegális kereskedelem nem csupán az eredményes hatósági felderítésekkel szorítható vissza, hanem össztársadalmi fellépést igényel.
\end{abstract}

Kulcsszavak: vám, legális, illegális, engedély, CITES, veszélyeztetett fajok, környezeti büncselekmények

\footnotetext{
HARNBERGER György, pénzügyőr őrnagy, vám- és pénzügyőri szakértő referens, Nemzeti Adó- és Vámhivatal Központi Irányítás Vám Főosztály Különleges Eljárások Osztálya

György HARNBERGER, Finance Guard Major, Expert Officer, National Tax and Customs Administration Central Management Customs Department

https://orcid.org/0000-0001-7700-9458; harnberger.gyorgy@nav.gov.hu

2 ZSIGMOND Csaba, rendőr alezredes, mesteroktató, NKE RTK, Bűnügyi, Gazdaságvédelmi és Kiberbűnözés Elleni Tanszék

Csaba ZSIGMOND, Police Lieutenant Colonel, Master Instructor, NUPS Faculty of Law Enforcement https://orcid.org/0000-0001-6765-7670; zsigmond.csaba@uni-nke.hu

3 Sziebig (2019) 157.
} 


\section{Bevezetés}

Az évszázados káros emberi tevékenység a biológiai sokféleség (biodiverzitás) hanyatlását, fajok egyedszámának csökkenését vagy pusztulását idézte elő. ${ }^{4} \mathrm{~A}$ környezeti bủncselekmények kimagasló hasznot eredményezhetnek alacsony kockázat mellett, így világszerte jellemzővé vált a szervezett búnözés egyre nagyobb térhódítása ezen a területen. ${ }^{5}$

A vadon élő állatok és növények, valamint a belölük készült termékek (például ajándéktárgyak, trófeák) emelkedő legális és illegális kereskedelme szintén veszélyezteti a változatos élővilág fennmaradását. Becslések szerint a legális forgalom értéke eléri a 159 milliárd dollárt, és mintegy 350 millió egyedet érint. ${ }^{6}$

A vadvilágot érintő jogellenes kereskedelem nyeresége évi 18-26 milliárd euróra tehetô. ${ }^{7}$ Szintén veszélyt jelent a populációkra nézve a természetes élőhelyek csökkenése, a környezetszennyezés és az őshonos fajokat kiszorító invazív fajok elszaporodása. ${ }^{8}$ A biológiai sokféleség csökkenését és a fajok kihalásának megakadályozását célzó küzdelemben a vámhatóságnak is szerepet kell vállalnia. A vámhatóság ellenőrzési tevékenysége e területen egyetemes természeti értékeink és környezetünk védelmére, vagyis a biodiverzitás megőrzésére irányul. Jelen cikk a veszélyeztetett fajok legális forgalmát érintő vámhatósági ellenőrzések alapvető szabályait és az illegális forgalom felderítésének tendenciáit kívánja bemutatni a vámhatóság és a rendőrség szakértőinek közremúködésével, valamint szakértői interjúkkal és adatbázisokból nyert adatok segítségével.

\section{A veszélyeztetett fajok kereskedelmét érintő környezetvédelmi politika}

A biológiai sokféleség kérdéskörét, egyúttal a veszélyeztetett fajok fennmaradását a nemzetközi közösség kiemelt kérdésként kezeli. Az 1992-ben Rio de Janeiróban aláírt Biológiai Sokféleség Egyezmény a hatóságok és a társadalmi szereplők közti együttmüködés erősítését, a képzések fontosságát emeli ki a fajok védelme érdekében. ${ }^{9}$ A biodiverzitás megőrzése az ENSZ közgyúlésein is rendszeresen felmerül. Az ENSZ közgyúlési határozatok kiemelik, hogy a veszélyeztetett fajok jogellenes kereskedelme

4 Egy évszázad alatt 12 millióról 400 ezerre csökkent az afrikai elefántok száma. Lásd Bodnár (2019). A halállomány 75\%-át túlhalásszák, átlagosan évente 13 millió hektár trópusi erdőt irtanak ki, a korallzátonyok 20\%-a pedig eltűnt. Lásd: Életbiztosításunk, természeti tőkénk: a biológiai sokféleséggel kapcsolatos, 2020-ig teljesítendő uniós stratégia, A Bizottság közleménye az Európai Parlamentnek, a Tanácsnak, a Gazdasági és Szociális Bizottságnak és a Régiók Bizottságának (2011) 1.

5 A Európai Bizottság 2017-es jelentése szerint a környezeti bűnözés értéke éves szinten 91-258 milliárd USD értékre tehető, és a globális gazdaság bővüléséhez képest kétszer-háromszor gyorsabb ütemben növekedik.

6 Marosi (2015)

7 A vadon élő állatokat és növényeket érintő bűncselekmények elleni küzdelem, az Európai Parlament 2014. január 15-i állásfoglalása a vadon élő növényekkel és állatokkal kapcsolatos bủncselekményekről (2014) 1. pont.

8 Életbiztosításunk, természeti tőkénk: a biológiai sokféleséggel kapcsolatos, 2020-ig teljesítendő uniós stratégia... (2011) 1.; Gyulai (2011) 15.

9 A Biológiai Sokféleség Egyezmény kihirdetéséről szóló 1995. évi LXXXI. törvény 5., 12. és 14. cikkelyei alapján. 
károkat okoz a környezetnek, de egyben biztonsági kockázatot is jelent, mivel a bủnözők a tevékenységükből származó hasznot más bűncselekmények (például kábítószerkereskedelem) finanszírozására fordítják. Az ENSZ határozatai a helyi és a regionális együttmüködés erősítését, illetve a nemzetközi összefogást sürgetik. ${ }^{10}$

Az EU-nak nagy szerepe van a környezetpolitika formálásában, mivel egyszerre felvevő piac és tranzitállomás is a veszélyeztetett fajok legális és illegális kereskedelme terén. ${ }^{11}$ Ezért az uniós hatóságok érdekeltek és felelősek egy jól működő ellenőrzési rendszer kialakításában. Az EU a biológiai sokféleség megőrzése és a veszélyeztetett fajok jogellenes kereskedelmének megakadályozása érdekében a 2016-2020 közti időszakra szóló biodiverzitási stratégiát és cselekvési tervet dolgozott ki. Az uniós stratégia az EU-tagállamok, a harmadik országok és a társadalom közti együttműködés, a közös hatósági fellépés és a képzés erősítését helyezi előtérbe. ${ }^{12} \mathrm{Az}$ EU cselekvési terv a jogellenes kereskedelem elleni intézkedéseket és azok céljait (például szoros együttműködés a feladó, a cél- és a tranzitországok között) határozza meg a tagállamok számára. ${ }^{13}$ A tanácsi rendelet végrehajtása érdekében 2007-ben kiadott bizottsági ajánlásban a tagállami és regionális együttmúködés mellett a fajok felismerésére irányuló képzés fontossága, valamint a közvélemény tájékoztatása is hangsúlyosan szerepel. Az ajánlás emellett felhívja a figyelmet a nemzeti hatóságok közötti együttműködésre, a kockázatkezelésen alapuló ellenőrzések alkalmazására, az ellenőrzési tapasztalatok és információk megosztásának szükségességére. ${ }^{14} \mathrm{~A}$ biológiai sokféleség megóvását hazánk is kiemelten kezeli. Magyarország Alaptörvénye szerint a biológiai sokféleség, továbbá a honos növények és állatok nemzeti örökségünk részét képezik, védelmükben az államnak és polgárainak is részt kell venniük. ${ }^{15}$ A 2015-2020 közti időszakra szóló nemzeti biodiverzitási stratégia kitér a veszélyeztetett fajok védelmének jelentőségére, fontosnak tartja a képzést, egyúttal kiemeli a vámhatóság, a rendőrség, a természetvédelmi hatóságok, az állat- és növényegészségügyi hatóságok szerepét a kereskedelem ellenőrzése során. ${ }^{16}$

$10 \quad$ Sziebig (2019) 28-29.

11 Sziebig (2018) 132.; Sziebig (2019) 111.; A Bizottság közleménye az Európai Parlamentnek, a Tanácsnak, az Európai Gazdasági és Szociális Bizottságnak és a Régiók Bizottságának. A vadon élő állatok és növények jogellenes kereskedelme elleni uniós cselekvési terv (2016) 3.

12 Életbiztosításunk, természeti tőkénk: a biológiai sokféleséggel kapcsolatos, 2020-ig teljesítendő uniós stratégia... (2011) 5-9.

13 A Bizottság közleménye az Európai Parlamentnek, a Tanácsnak, az Európai Gazdasági és Szociális Bizottságnak és a Régiók Bizottságának. A vadon élő állatok és növények jogellenes kereskedelme elleni uniós cselekvési terv (2016) 6-7.

14 A vadon élő állat- és növényfajok számára kereskedelmük szabályozása által biztosított védelemről szóló 338/97/EK tanácsi rendelet végrehajtását segítő intézkedésekről szóló 2007/425/EK bizottsági ajánlás (2007). II. cím e)-h) pontjai, III. cím a)-b), d), h-i) k)-l) pontjai.

15 Magyarország Alaptörvénye P) cikk (1) bekezdése alapján.

16 A biológiai sokféleség megőrzésének 2015-2020 közötti időszakra szóló nemzeti stratégiájáról szóló 28/2015. (VI. 17.) OGY határozat 2.1.15 cím, 3.2. cím I. stratégiai terület 4. célkitűzés, VI. stratégiai terület 18. célkitúzés alapján. 


\section{A veszélyeztetett fajok kereskedelmére vonatkozó jogszabályok}

A veszélyeztetett fajok kereskedelme kontinenseket köt össze, így az erre irányadó jogi keretrendszert nemzetközi, uniós és nemzeti szinteken alakították ki. A nemzetközi jogi kereteket az 1973. március 3-án elfogadott, a veszélyeztetett vadon élő állat- és növényfajok nemzetközi kereskedelméről szóló washingtoni egyezmény (a továbbiakban: CITES-egyezmény) biztosítja. A megállapodásnak 183 ország a tagja, és közel 35 ezer faj kereskedelmét szabályozza. Az Európai Unió (a továbbiakban: EU) saját szabályrendszert dolgozott ki a témakörrel összefüggésben. ${ }^{17}$

Az uniós rendelkezéseket az alábbi jogszabályok tartalmazzák:

- a vadon élő állat- és növényfajok számára kereskedelmük szabályozása által biztosított védelemrôl szóló 338/97/EK tanácsi rendelet (a továbbiakban: tanácsi rendelet) a kereskedelem és az eljárások alapvető szabályait határozza meg,

- a tanácsi rendelet végrehajtására vonatkozó részletes szabályok megállapításáról szóló 865/2006/EK bizottsági rendelet (a továbbiakban: bizottsági rendelet) a tanácsi rendelet végrehajtásának szabályait határozza meg,

- a tanácsi rendeletben előírt engedélyek, bizonyítványok és más okmányok mintáira vonatkozó szabályok megállapításáról és a 865/2006/EK bizottsági rendelet módosításáról szóló 792/2012/EU bizottsági végrehajtási rendelet (a továbbiakban: végrehajtási rendelet) az engedélyek felhasználásának szabályait határozza meg,

- az egyes vadon élő állat- és növényfajok példányai unióba történő behozatalának a tanácsi rendeletben foglaltak szerinti tilalmáról szóló 2019/1587 bizottsági végrehajtási rendelet (úgynevezett tilalmi rendelet) egyes veszélyeztetett fajok meghatározott harmadik országokból (például egyes békafajok Peruból) az EU-ba történő behozatalát tilalmazza.

A CITES-egyezmény a nemzetközi kereskedelmet, míg a tanácsi rendelet az EU-n belüli, továbbá az EU-n kívüli (harmadik) országok közti forgalmat szabályozza. A témakör jelentőségét emeli ki, hogy egyes védett fajok (például fóka, hóvirág) szállítása esetén további uniós és/vagy nemzeti természetvédelmi jogszabályok előírásait is alkalmazni kell. ${ }^{18}$ A CITES-egyezmény és a tanácsi rendelet a védelem alá eső állat- és növényfajokat veszélyeztetettségi helyzetük alapján csoportosítja. Így a CITES-egyezmény három függelékben (I-III.), míg a tanácsi rendelet négy mellékletben (A-D) szerepelteti a veszélyeztetett fajokat. A függelékek és a mellékletek tartalma néhány kivételtől eltekintve megegyezik. Az I. függelékben és az „A” mellékletben a kipusztulással fenyegetett fajok (például tigris, elefánt, orchidea) szerepelnek. A II. függelék és a „B” melléklet

17 Az EU a liszaboni szerződéssel jogi személyiséggé vált és 2015. július 8-án a 2015/451 tanácsi határozat alapján csatlakozott a CITES egyezményhez. Sziebig (2018) 123.

18 Az ismertebbek: a fókatermékek kereskedelméről szóló 1007/2009/EK európai parlamenti és tanácsi rendelet, illetve a természet védelméről szóló 1996. évi LIII. törvény. 
tartalmazza azokat a fajokat (például oroszlán, víziló, rózsafa), amelyek még nincsenek kritikus helyzetben. A III. függelékben és a „C” mellékletben a nemzetközi beavatkozással védelmezett fajok (például tatu, cibetmacska) kaptak helyet. A CITES-egyezmény és a tanácsi rendelet az adott faj példányának minden megjelenési formájára (élő és élettelen egyedek, azok bármely könnyen felismerhető része vagy származéka) kiterjed. ${ }^{19}$ Ugyanakkor a tanácsi rendelet bizonyos fajok számára a CITES-egyezményhez képest szigorúbb védelmet biztosít, különösen a behozatali engedélyezés terén. A tanácsi rendeletnek van egy „D” melléklete, amelyben a CITES-egyezményben nem szereplő fajok (például vörös róka, izlandi zuzmó) szerepelnek. A témakört érintő magyar rendelkezéseket a veszélyeztetett vadon élő állat- és növényfajok nemzetközi kereskedelmét szabályozó nemzetközi és európai közösségi jogi aktusok végrehajtásának egyes szabályairól szóló 292/2008. (XII. 10.) Korm. rendelet (a továbbiakban: Korm. rendelet) foglalja magában.

\section{Engedélyezés}

A CITES-egyezmény és a tanácsi rendelet hatálya alá tartozó fajok példányainak behozatala és kivitele CITES-engedélyek, illetve egyéb okmányok (bizonyítványok, igazolások, bejelentések) bemutatásához kötött. A hazánk területén történő átszállításhoz (tranzit) nem kell CITES-engedély. A tanácsi rendelet végrehajtása érdekében a tagállamok nemzeti CITES igazgatási hatóságokat jelölnek ki, amelyek engedélyezési feladatot is ellátnak. ${ }^{20}$ Magyarország területén ezt a tevékenységet és az engedélyek kiállítását az Agrárminisztérium Biodiverzitás és Génmegőrzési Főosztály (a továbbiakban: $A M)$ végzi. A kereskedelem szigorú felügyelet alatt tartása érdekében a tanácsi rendelet „A-C” mellékleteiben feltüntetett fajok példányainak behozatalához a CITES import engedélyen kívül a feladó ország CITES hatósága által kiállított exportengedély vagy egyéb kiviteli okmány (például újrakiviteli bizonyítvány, származási igazolás) is szükséges, amennyiben az érintett faj a CITES-egyezményben is szerepel. A kivitelekhez a CITES-exportengedély vagy más okmány (újrakiviteli bizonyítvány) is elegendő. A tanácsi rendelet „D” mellékletébe tartozó fajok esetében csak a behozatalhoz kötődik okmánybenyújtási kötelezettség (importbejelentés). A speciális felhasználási célhoz kötött szállítások (például kiállítás, cirkuszok, tenyésztés) a bizottsági rendeletben megjelölt bizonyítványok benyújtásához kötött. ${ }^{21} \mathrm{Az}$ engedélyeket, bizonyítványokat jogi személyek és magánszemélyek egyaránt megszerezhetik.

A veszélyeztetett fajok behozatala és kivitele esetén az állat- és növényegészségügyi rendelkezéseket is figyelembe kell venni. Élő állat vagy állati eredetű termék behozatala során Közös Egészségügyi Beléptetési Okmány, kivitel esetén állategészségügyi bizonyítvány szükséges, mindkét okmányt a megyei kormányhivatal munkatársa (hatósági

\footnotetext{
19 A CITES-egyezmény kihirdetéséről szóló 2003. évi XXXII. törvény I. cikk b) pontja és a tanácsi rendelet 2. cikk t) pontja alapján.

20 A tanácsi rendelet 4. cikk (1), 5. cikk (1) és 13. cikk (1) bekezdései alapján.

${ }^{21}$ A bizottsági rendelet 30. cikke szerinti vándorkiállítás-bizonyítvány az egyik legismertebb.
} 
állatorvos) állítja ki. A növényegészségügyi ellenőrzés alá eső termékek, élő növények behozatalához és kiviteléhez növényegészségügyi bizonyítványt kell beszerezni, amelyet az importálás esetén a harmadik ország illetékes hatósága, az exportálás esetén a növény- és talajvédelmi hatáskörben eljáró megyei kormányhivatalok állítanak ki. ${ }^{22}$ A védett és a fokozottan védett növény- és állatfajok szállításához az országos és területi természetvédelmi hatóságok (Pest Megyei Kormányhivatal, megyei kormányhivatalok) engedélye is szükséges lehet. ${ }^{23}$ A CITES-engedélyeknek és egyéb bizonyítványoknak a vámeljárás kezdeményezésekor rendelkezésre kell állniuk. ${ }^{24}$

\section{A vámhatósági ellenórzés alapvető szabályai}

A vámhatóság a tanácsi rendeletben szereplő fajok harmadik országok vonatkozásában bonyolódó behozatalát, kivitelét és tranzitforgalmát ellenőrzi. ${ }^{25} \mathrm{~A}$ vámellenőrzés és a vámeljárások végrehajtása az Uniós Vámkódex létrehozásáról szóló 952/2013/EU európai parlamenti és tanácsi rendeletben (a továbbiakban: UVK) foglaltakon alapul. Az UVK alapján a harmadik országokból behozott nem uniós árukat vám elé kell állítani, az ilyen áru vámfelügyelet alatt áll, és vámellenőrzés alá vonható. ${ }^{26} \mathrm{~A}$ vámfelügyelet addig áll fenn, amíg az adott áru vámjogi helyzetének meghatározásához (gyakorlatilag vámeljárás alá vonásáig) az szükséges, továbbá az ilyen áru a vámhatóság engedélye nélkül a vámfelügyelet alól nem vonható ki. Az UVK alapján az EU-ból kiszállítandó árukat kiviteli vámeljárás alá kell vonni. ${ }^{27} \mathrm{~A}$ vámhatóság minden általa szükségesnek

22 Az élő állatok és növények, az állati és növényi eredetủ termékek behozatalára az élelmiszer- és takarmányjog, valamint az állategészségügyi és állatjóléti szabályok, a növényegészségügyi szabályok, és a növényvédő szerekre vonatkozó szabályok alkalmazásának biztosítása céljából végzett hatósági ellenőrzésekről és más hatósági tevékenységekről, továbbá a 999/2001/EK, a 396/2005/EK, az 1069/2009/EK, az 1107/2009/EK, az 1151/2012/EU, a 652/2014/EU, az (EU) 2016/429 és az (EU) 2016/2031 európai parlamenti és tanácsi rendelet, az 1/2005/EK és az 1099/2009/EK tanácsi rendelet, valamint a 98/58/EK, az 1999/74/EK, a 2007/43/EK, a 2008/119/EK és a 2008/120/EK tanácsi irányelv módosításáról, és a 854/2004/EK és a 882/2004/EK európai parlamenti és tanácsi rendelet, a 89/608/EGK, a 89/662/EGK, a 90/425/EGK, a 91/496/EGK, a 96/23/EK, a 96/93/EK és a 97/78/EK tanácsi irányelv és a 92/438/ EGK tanácsi határozat hatályon kívül helyezéséről szóló 2017/625 európai parlamenti és tanácsi rendelet (a hatósági ellenőrzésekről szóló rendelet), valamint a hatósági ellenőrzések információkezelési rendszerének és a rendszer elemeinek múködésére vonatkozó szabályok megállapításáról szóló 2019/1715 bizottsági végrehajtási rendelet (a hatósági ellenőrzések információkezelési rendszeréről szóló rendelet) irányadó. Az állatok, állati eredetű termékek kivitele esetén a harmadik országokba való kivitelre szánt egyes élő állatok és termékek közösségen belüli kereskedelmére vonatkozó részletes szabályokról szóló 93/444/EGK bizottsági határozat alkalmazandó. Az élő növények, növényi termékek behozatalára és kivitelére a növénykárosítókkal szembeni védekező intézkedésekről, a 228/2013/EU, a 652/2014/EU és az 1143/2014/EU európai parlamenti és tanácsi rendelet módosításáról, valamint a 69/464/EGK, a 74/647/EGK, a 93/85/EGK, a 98/57/EK, a 2000/29/EK, a 2006/91/EK és a 2007/33/EK tanácsi irányelv hatályon kívül helyezéséről szóló 2016/2031 európai parlamenti és tanácsi rendelet is vonatkozik.

23 A természet védelméről szóló 1996. évi LIII. törvény 42. § (3) bekezdés c) pontja és 43. § (2) bekezdés i) pontja alapján. A védett és fokozottan védett fajokat a fokozottan védett barlangok köréről, valamint az Európai Közösségben természetvédelmi szempontból jelentős növény- és állatfajok közzétételéről szóló 13/2001. (V. 9.) KöM rendelet 1-2. melléklete tartalmazza. Az országos és területi természetvédelmi hatóságok a környezetvédelmi és természetvédelmi hatósági és igazgatási feladatokat ellátó szervek kijelöléséről szóló 71/2015. (III. 30.) Korm. rendelet 8. és 8/A. §-ában szerepelnek.

24 A bizottsági rendelet 13. cikk (2) bekezdése alapján.

25 A tanácsi rendelet 4. cikk (1) és 5. cikk (1), illetve a Korm. rendelet 3. § (3) bekezdései alapján.

26 Az UVK 134. cikk (1) és 139. cikk (1) bekezdése alapján.

27 Az UVK 169. cikk (1) bekezdése alapján. 
tartott ellenőrzést (például az áru vizsgálata, a vámeljárásra vonatkozó vám-árunyilatkozat és az ahhoz tartozó okmányok meglétének vizsgálata) elvégezhet. ${ }^{28} \mathrm{~A}$ vámhatósági ellenőrzés mértéke az adott faj tanácsi rendelet szerinti besorolásán alapul. A vámhatóság a vám-árunyilatkozat és az ahhoz tartozó okmányok (kereskedelmi számla, fuvarokmány, CITES-engedélyek) adatait ellenőrzi. A vizsgálat alapvető célja a vámeljárásra bejelentett faj vagy a belőle készült termék azonosítása, majd az esetleges engedélykötelezettség megállapítása, ezt követően a CITES-engedélyek meglétének, adattartalmának áttekintése. A vámhatóság minden esetben átfogó fizikai áruvizsgálatot tart az eljárás alá vont példány vagy termék azonosságának megállapítása érdekében. Ha a vizsgálat során hiányosság nem állapítható meg, és a CITES-engedélyt is benyújtották, a vámhatóság elvégzi a vámeljárást. Amennyiben a vámhatósági ellenőrzés hiányosságot állapít meg (például hiányzik az engedély) vagy az adott faj nem azonosítható (és az engedélykötelezettség nem állapítható meg), a vámhatóság felveszi a kapcsolatot az AM-mel az engedélykötelezettség megállapítása érdekében. Ilyen esetekben a vámhatóság az AM szakmai útmutatásai alapján jár el. ${ }^{29} \mathrm{~A}$ magyar vámhatóság szorosan együttműködik az engedélyezést végző hazai CITES igazgatási hatósággal (AM), figyelemmel arra, hogy az eljárás alá vont fajok azonosításához és az engedélykötelezettség megállapításához a társhatóság rendelkezik megfelelő szakmai ismeretekkel. Amennyiben a társhatóság kockázatot állapít meg, vagy gyanús ügyletről szerez tudomást tevékenységének ellátása során, azt haladéktalanul jelzi a vámhatóság felé. Az információk értékelését követően megtörténik az adatok vámhatósági kockázatelemzési folyamatba történő becsatornázása és az esetleges további vámhatósági intézkedések foganatosítása. A magyar vámhatóság és a veszélyeztetett fajok kereskedelmének felügyeletében érintett társhatóságok (AM, természetvédelmi hatóságok, állat- és növényegészségügyi ellenőrzést végző szervek) együttmüködése megfelelő. Jellemzően az áruazonosítás, illetve ezzel összefüggésben az esetleges engedélykötelezettség meghatározása céljából történik kapcsolatfelvétel a felek között.

A veszélyeztetett fajokat érintő hazai vámeljárások 2018. évi adatait az 1. ábrán, a 2019. évi adatokat a 2. ábrán szereplő diagram tartalmazza. Az adatok alapján megállapítható, hogy a veszélyeztetett fajokat érintő forgalom a külső határszakaszokon, ezen belül elsősorban a NAV Repülőtéri Igazgatóságán és a NAV Csongrád Megyei Adó- és Vámigazgatóságán (ezen belül Röszke Határkirendeltségen) koncentrálódik. ${ }^{30}$ Hazánkban alapvetően a tanácsi rendelet „A” és „B” mellékleteiben feltüntetett fajok (például oroszlán, leopárd, karakál, rózsafa, aligátor) és azokból készült termékek kereskedelme tapasztalható.

\footnotetext{
Az UVK 46. cikk (1) bekezdése és UVK 188. cikke alapján.

29 Suba-Szendi (2018) 137.

30 Az adatok a magyar vámhatóság saját fejlesztésű VAMSTAT elnevezésű statisztikai adatszolgáltatási rendszeréből származnak. Az alkalmazásban a veszélyeztetett fajokat érintő vámeljárások adatait rögzítik. Suba-Szendi (2018) 129.
} 


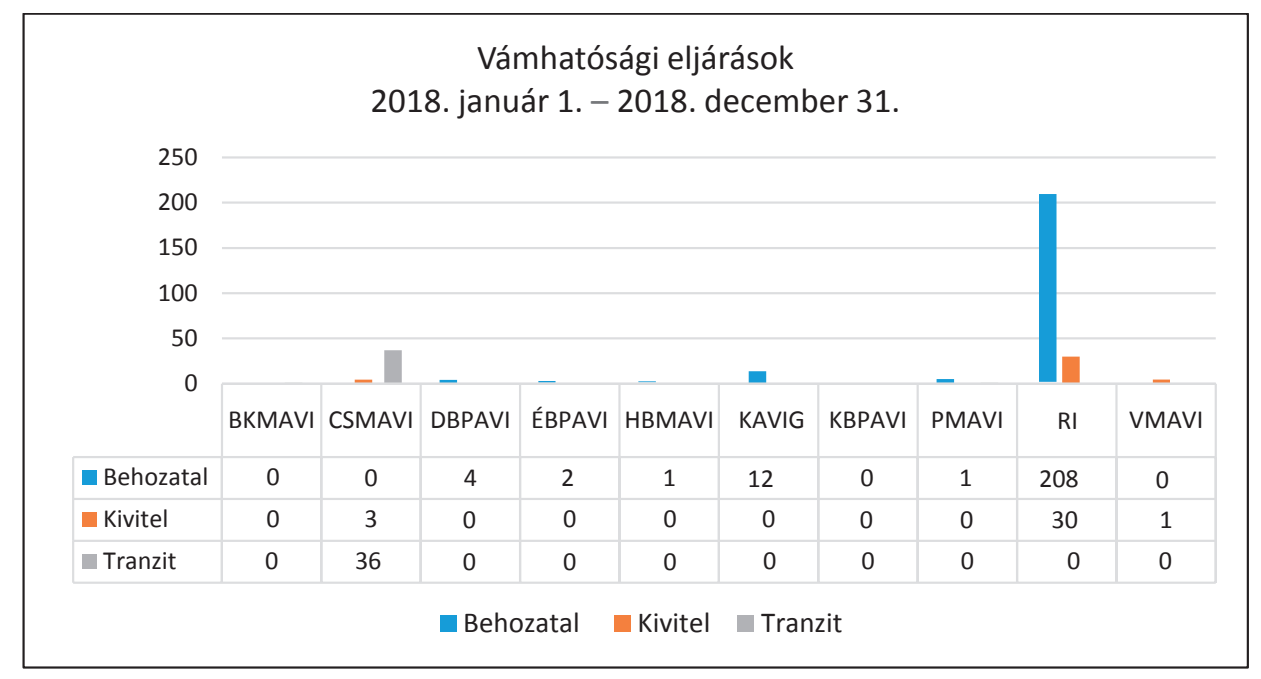

1. ábra: Vámhatósági eljárások 2018-ban. Forrás: VAMSTAT adatbázis

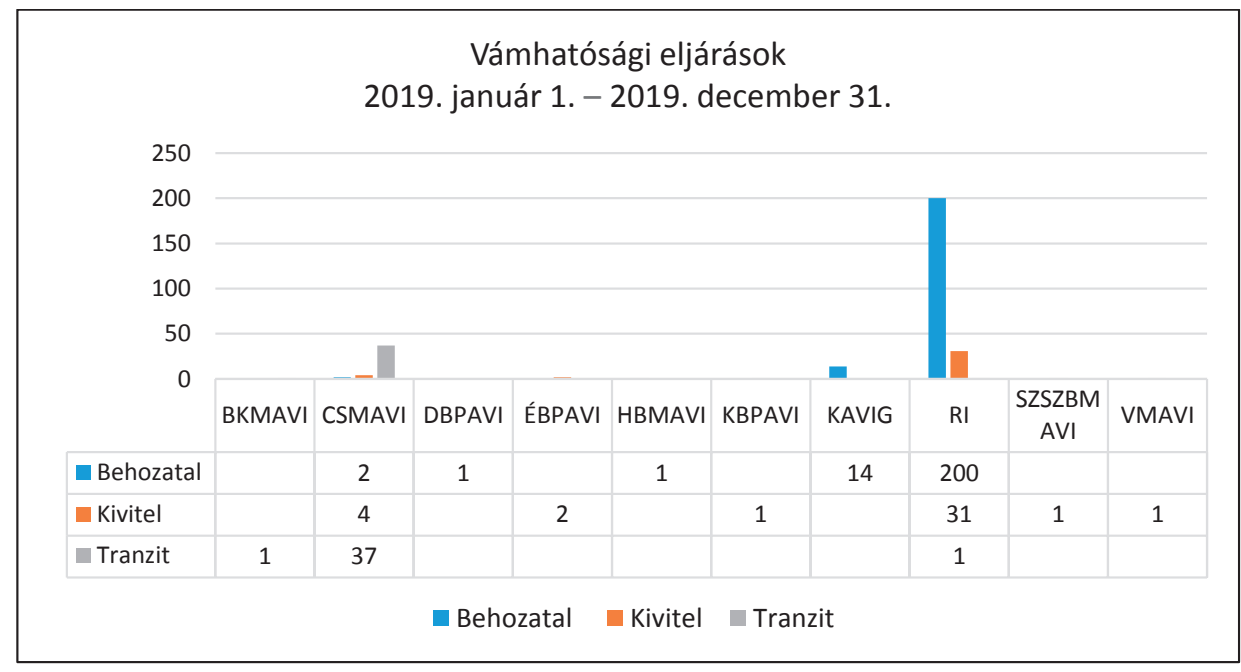

2. ábra: Vámhatósági eljárások 2019-ben. Forrás: VAMSTAT adatbázis

Szükséges kiemelni, hogy a tanácsi rendelet illetékességi szabályokat tartalmaz, amelyek alapján kijelölhetők azok a vámszervek, ahol a vámhatósági eljárások bonyolódhatnak. Ennek megfelelően a tanácsi rendelet hatálya alá tartozó példányok és termékek csak a Korm. rendelet 6 . számú mellékletében feltüntetett, állat- vagy növényegészségügyi 
határállomással rendelkező határátkelőhelyeken léphetnek be harmadik országból az EU területére, illetve léphetnek ki harmadik ország területére. ${ }^{31}$

\section{A nemzetközi jogellenes kereskedelem jellemzői}

A veszélyeztett állat- és növényfajok illegális nemzetközi kereskedelme a 20. század végére és a 21. századra óriási méreteket öltött világszerte, ${ }^{32}$ ami egyre nagyobb fenyegetést jelent az élővilágra, és az emberiségre. A környezeti bűncselekmények bizonyos kategóriái - orvvadászat, védett fajok illegális kereskedelme - olyan kimagasló hasznot eredményezhetnek alacsony kockázat mellett, hogy világszerte jellemzővé vált a szervezett bünözés egyre nagyobb térhódítása ezen a területen. ${ }^{33}$

A nemzetközi közösségek, egyes nemzeti bűnüldöző hatóságok körében e bűncselekmény-kategória sokáig nem élvezett kiemelt prioritást. Azonban a szervezett bűnözés egyre nagyobb térhódítását felismerve a környezeti bűnözésben az utóbbi években egyre több, fokozottabb nemzetközi összefogásra irányuló törekvés figyelhető meg, illetve e bűncselekmény-kategória fokozottabb prioritást kap. ${ }^{34}$ Ennek egyik jele, hogy a súlyos bűncselekmények és a szervezett bűnözéssel szembeni fellépés jövőbeli uniós prioritásainak meghatározásával összefüggésben a bizottság támogatta az Europol által azonosított kiemelt bűnügyi fenyegetések ${ }^{35}$ - többek között a környezeti bűnözés - kiemelt prioritássá minősítését, illetve a bizottság álláspontja szerint a környezeti bűnözés elleni fellépésre a jövőben kiemelt figyelmet és jelentős anyagi forrásokat kell biztosítani. ${ }^{36}$

Az ENSZ Bűnmegelőzési és Kábítószerügyi Hivatala (UNODC) a „vadon élő állatok és növények illegális kereskedelme” témában 2016-ban egy átfogó jelentést készített. A jelentésből többek között megismerhető, hogy 1999-től 2015-ig világszerte az eljáró hatóságok milyen arányban foglaltak le az egyes osztályokba tartozó állatokat. Eszerint a lefoglalt állatok 30\%-a hüllő, 28\%-a emlős, 17\%-a korall, 9\%-a madár, 6\%-a hal és $10 \%$ egyéb osztályba sorolandó. ${ }^{37}$

A kereslet különböző okokból jelent meg: étkezési, gyógyászati (orrszarvú tülök, gyógynövények), divat (hüllők bőre), kozmetikai célok vagy hobbiállatok tartása (papagájfélék) céljából, illetve dísztárgyak készülhetnek belőlük (elefántcsont). ${ }^{38}$ Ezért az állatokat és növényeket élve vagy elpusztítva, feldolgozva szállítják.

Az egyes illegális termékek (kábítószer, fegyver stb.) nemzetközi csempészetéhez hasonlóan megkülönböztethetők forrás-, tranzit- és célországok.

\footnotetext{
1 A tanácsi rendelet 12. cikk (1)-(3) bekezdései és a Korm. rendelet 13. §-a alapján.

World wildlife crime report, Trafficking in protected species (2016) 17.

${ }_{33}$ Az Európai Bizottság 2017-es jelentése szerint a környezeti bűnözés értéke éves szinten 91-258 milliárd USD-értékre tehető, és globális gazdaság bővüléséhez képest kétszer-háromszor gyorsabb ütemben növekedik.

34 Zsigmond (2018) 169.

35 Nyeste (2019) 52.

36 A bizottság jelentése az Európai Parlamentnek, az Európai Tanácsnak, és a Tanácsnak Hatodik eredményjelentés a hatékony és valódi biztonsági unió megvalósításáról (2017) 12.

37 World wildlife crime report, Trafficking in protected species (2016) 31.

38 World wildlife crime report, Trafficking in protected species (2016) 13.
} 
A forrásországokra általában jellemző (amelyek elsősorban a harmadik világbeli úgynevezett fejlődő országok), hogy igen gazdag élővilággal rendelkeznek, azonban gazdaságilag gyengék, a szegénység általános, erős a korrupciós fertőzöttség, gyengén múködő rendészeti, igazságszolgáltatási rendszerük van, amelynek köszönhetően a védett fajok illegális orvvadászata, az országból való illegális exportja sem ütközik komolyabb akadályba. ${ }^{39}$

Tranzitországnak tekinthetők azok az államok, amelyek területén szárazföldi, vízi vagy légi úton a védett fajokat a csempészetet végző személyek átviszik. ${ }^{40} \mathrm{~A}$ tevékenységben nem minden esetben szerepelnek tranzitországok, például ha a csempészet szomszédos országok között bonyolódik, vagy közvetlen légi, vízi járaton keresztül történik e tevékenység, egymástól távoli országok között.

A célországok rendszerint gazdasági, ipari szempontból fejlettebb országok, amelyekben az élővilág kevésbé gazdag, mint a forrásországban.

Az Európai Unió tagállamai egyaránt tekinthetők tranzit- és célországoknak. Tranzitországok elsősorban az EU azon államai, ahol a nagyobb nemzetközi repülőterek és kikötők találhatók, úgymint Franciaország, Belgium, Hollandia és Németország, ${ }^{41}$ illetve célországok azok, ahol az ilyen típusú áruk iránt magas a kereslet, és ezért magas áron értékesíthetők ezek a termékek a feketepiacon. Az EU területén évente átlagosan 2500 esetben foglalnak le a hatóságok harmadik országból származó veszélyeztett állat- vagy növényfajokat, mivel általában az Európai Unióban a különböző egzotikus védett állat- és növényfajok iránt igen magas a kereslet. ${ }^{42}$

Az EU-TWIX ${ }^{43}$ adatbázis 2012-es adatai szerint a veszélyeztett állati vagy növényi termékek lefoglalása az alábbiak szerint alakult az EU területén:

Veszélyeztetett növények, azok származékai, illetve azokból készült gyógyhatású termékek lefoglalása több mint 3 millió árucikk esetében összesen több mint $3500 \mathrm{~kg}$ mennyiségben. Elefántcsont 1523 példány, több mint $70 \mathrm{~kg}$, élő hüllők 812 példány, hüllők származékai (például krokodilbőr vagy kígyóbőr) 1629 példány, kaviár 51 kg, emlősök vagy azokból készült származékok 316 példány, illetve korallok 1387 példány körülbelül 2850 kg mennyiségben.

Az adatbázis szerint a csempészek az alábbi módszereket alkalmazzák: konténerben, legális teherszállítmány közé rejtve, személyi poggyászban, postai úton, járművek helyiségeiben elrejtve, jármüvekben kialakított rejtekhelyeken, a csempészett termék átalakításával, illetve az utas ruhája alá rejtve. A szállítási módok közül az alábbi 5 típus ismert: légi úton (ez a leginkább jellemző), szárazföldön, amely egyaránt jelenthet

\footnotetext{
9 Uhm (2016) 103-111.

40 Az Európai Unió nagyobb nemzetközi repülőterei (Amsterdam), kikötői (Hamburg) sok esetben tranzitszerepet töltenek be egyes védett fajok vagy azok származékainak csempészetében, így például az elefántcsont, orrszarvú tülök Távol-Keletre való csempészetében.

41 TRAFFIC... (2013) 1.

42 Sina et al. (2016) 30.

43 EU-Twix adatbázis: A Traffic nemzetközi civil szervezet által müködtetett adatbázis, amely a hatóságok által lefoglalt védett állat- és növényfajok adatait tartalmazza.
} 
személygépkocsival, tehergépkocsival vagy akár gyalogosan való csempészetet, folyón vagy tengeri úton, illetve vasúton.

\section{A magyarországi jogellenes szállítások (csempészet) jellemzői}

A jogellenes szállítás (csempészet) akkor állapítható meg, ha a vámeljárást a szükséges engedély vagy bizonyítvány hiányában vagy az ágazati jogszabályokban előírt feltételektől eltérő módon kezdeményezik (például az engedély adatai eltérnek az ellenőrzés során tapasztaltaktól). A külső határon és belterületen is realizálható a felderítés. Ilyen esetben az eljárás nem végezhető el addig, míg az eljárásban érintett ügyfél a szükséges érvényes engedélyeket vagy bizonyítványokat be nem mutatja. Jogellenes szállítás felderítésekor a magyar vámhatóság gondoskodik a szállítmány jegyzőkönyv felvétele mellett történő visszatartásáról és behozatal esetében a szállítmány vámhatósági felügyelet alá vételéről (az uniós vámjog végrehajtásáról szóló 2017. évi CLII. törvény 171. §-a szerinti vámhatósági rendelkezés alá vonásáról). Ezt követően a vámhatóság a megállapításairól és intézkedéseiről értesíti az AM-et ${ }^{44}$ (az eljáráshoz tartozó okmányok, a szállítmányról készített fényképek megküldésével), valamint az adott faj tulajdonságai alapján érintett természetvédelmi hatóságokat. A vámhatóság az értesítéseket követően a megkeresett társhatóságok szakmai útmutatásai alapján jár el. A visszatartott fajok élő példányainak elhelyezéséről a társhatóságok döntenek, elhelyezésükre a területileg illetékes állatkertekben (beleértve a vadasparkokat) vagy botanikus kertekben kerülhet sor. Fontos kiemelni, hogy a veszélyeztetett fajokból készült termékek (például kagyló, tengeri csillag, szőrme) nagy része ajándéktárgyként kapható a világ számos részén, így megvételükkel és az engedély nélküli behozatallal a Büntető Törvénykönyvről szóló 2012. évi C. törvény 242. § (1) bekezdése szerinti természetkárosítás bűncselekmény elkövetése valósul meg. Ha ez a vámhatósági ellenőrzések során megállapítást nyer, akkor büntetőeljárást vezetnek be.

A nemzetközi szakirodalomhoz és elemzésekhez hasonlóan megvizsgáltuk a Nemzeti Adó- és Vámhivataltól kapott adatok és szakértői interjúk segítségével, hogy hazánk mely ország (forrás, tranzit, cél) szerepét tölti be, továbbá milyen állat- és növényfajokra követik el az illegális szállítást, illetve milyen módszert alkalmaznak a csempészek.

A rendelkezésre álló adatok alapján megállapítható, hogy az elmúlt öt évben hazánk elsősorban a tranzit-, illetve célország szerepét töltötte be az illegális csempészetben.

Korábbi kutatások és tanulmányok alapján ${ }^{45}$ kijelenthető, hogy ez nem mindig volt így, hazánk korábban a forrásország szerepét is betöltötte.

A NAV Központi Irányítás Rendészeti Főosztály által készített kimutatás szerint a veszélyeztetett fajok közül a növények csempészete jellemző elsősorban, gyógyászati (például az indiai bogáncsból gyógykészítmények) vagy dekorációs célból (hóvirág), ezt

\footnotetext{
44 A Korm. rendelet 4 . $§(1)$ és $20 . \S$ (1) bekezdése alapján.

45 Tilki (2004) 92.
} 
követik a madarak (élve, a szállítás során elpusztulva vagy feldolgozva), illetve az emlősök, majd hüllők származékai (állatbőrök, ezekből készült termékek), végül a korallok darabjai.

A kigyüjtött adatok szerint a nemzetközi trendeknek megfelelöen a csempészet elsősorban légi úton jellemző, elsősorban küldeményként érkeznek az illegális termékek harmadik országokból, másodsorban közúti személyforgalommal (autóbusz, mikrobusz, személygépkocsi) déli és keleti szomszédainktól (Szerbia, Ukrajna, Románia).

\section{Jogellenes szállítás légi úton}

Az alábbi táblázatok alapján megállapítható, hogy légi úton leginkább a CITES védelem alatt álló növények, állatok származékainak csempészete jellemző, élő állatokat (például üvegangolna-ivadékokat) csupán néhány esetben csempésznek.

1. táblázat: A Liszt Ferenc nemzetközi repülōtéren CITES-védelem alatt álló növények és állatok lefoglalási adatai éves bontásban (2014-2018). Forrás: NAV Központi Irányítás Rendészeti Főosztály

\begin{tabular}{|c|c|c|}
\hline Év & Utasforgalom tranzit-/belépő utasok & Küldemény \\
\hline 2014 & 9 & 27 \\
\hline 2015 & 6 & 17 \\
\hline 2016 & 5 & 11 \\
\hline 2017 & 5 & 9 \\
\hline 2018 & 4 & 0 \\
\hline
\end{tabular}

2. táblázat: A Liszt Ferenc nemzetközi repülőtéren lefoglalt, CITES-védelem alatt álló növényi és állati származékok rendszertani besorolás szerinti megoszlása (2014-2018). Forrás: NAV Központi Irányitás Rendészeti Főosztály

\begin{tabular}{|c|c|c|c|c|c|}
\hline & $\mathbf{2 0 1 4}$ & $\mathbf{2 0 1 5}$ & $\mathbf{2 0 1 6}$ & $\mathbf{2 0 1 7}$ & $\mathbf{2 0 1 8}$ \\
\hline Hüllő & 11 & 3 & 5 & 3 & 0 \\
\hline Hal & 0 & 0 & 0 & 0 & 0 \\
\hline Emlős & 5 & 3 & 3 & 8 & 0 \\
\hline Növény & 12 & 6 & 6 & 0 & 1 \\
\hline Korallok & 6 & 5 & 2 & 3 & 0 \\
\hline
\end{tabular}


3. táblázat: A Liszt Ferenc nemzetközi repülōtéren lefoglalt CITES-védelem alatt álló éló növények és állatok rendszertani besorolás szerinti megoszlása (2014-2018). Forrás: NAV

Központi Irányitás Rendészeti Főosztály

\begin{tabular}{|c|c|c|c|c|c|}
\hline & $\mathbf{2 0 1 4}$ & $\mathbf{2 0 1 5}$ & $\mathbf{2 0 1 6}$ & $\mathbf{2 0 1 7}$ & $\mathbf{2 0 1 8}$ \\
\hline Növény & 3 & 1 & 0 & 0 & 1 \\
\hline Hal & 2 & 0 & 1 & 0 & 0 \\
\hline Madár & 1 & 0 & 0 & 0 & 0 \\
\hline
\end{tabular}

Az alábbi kimutatás szerint a CITES-védelem alatt álló állati vagy növényi termékeket elsősorban küldeményként kísérelték meg csempészni, ezt követi az utasforgalomban való csempészet (feladott csomag), kézi poggyászból, ruházatból az elmúlt öt évben nem került elő csempészett védett állat- vagy növényfaj. Jellemzően a küldeményként feladott csomagokban a csempészett illegális áru mennyisége a legtöbb esetben nagyobb volt (esetenként elérte az 50 kg-ot).

4. táblázat: A Liszt Ferenc nemzetközi repülötéren CITES-védelem alatt álló növények és állatok csempészési módszerei (2014-2018). Forrás: NAV Központi Irányítás Rendészeti Főosztály

\begin{tabular}{|c|c|c|}
\hline Utas feladott poggyászából & Küldeményként & Kézi poggyászból, ruházatból \\
\hline 21 & 72 & 0 \\
\hline
\end{tabular}

$\mathrm{Az}$ EU egyes tagállamaiban (Németország, Hollandia, Belgium) a lefoglalások számát illetően vezető helyen állnak a különböző veszélyeztett növényekből készült gyógyhatású készítmények, amelyek jellemzően Ázsiából származnak. ${ }^{46}$ Légi úton hazánkba is leginkább a Távol-Keletről vagy Közép-Ázsiából származó veszélyeztetett növényekből készült gyógyhatású készítményeket csempésznek, amelyek leginkább küldeményként érkeznek. E növények a CITES listáján szerepelnek, az egyik ilyen kedvelt növény az indiai törpebogáncs, amelyből különböző gyógyhatású készítményeket, krémeket, tablettákat gyártanak. A növény a Himalája nyugati részén terem 2500 métertől a 3000 méteres tengerszint feletti magasságig. Gyógyító hatásának köszönhetően az utóbbi évtizedekben kritikusan veszélyeztett faj lett, ezért felkerült a CITES I. függelékébe. A faj veszélyeztetettségére és a nemzetközi védelemre tekintettel az indiai kormány megtiltotta a növény vagy származékainak exportját.

A forrásországokban e növények gyưjtése vagy engedélyhez kötött, vagy tiltott, azonban az általános szegénységre való tekintettel az illegális gyújtés egyre elterjedtebb, mivel családok mindennapi megélhetését biztosítja. ${ }^{47} \mathrm{~A}$ gyüjtókre épül a nemzetközi

\footnotetext{
46 Sina et al. (2016) 56.

47 Maqbool (2015)
} 
csempész- és kereskedőhálózat, amelynek segítségével a termékek elhagyják a forrásországot és az Európai Unió területére érnek. A csempészek nem ritkán hamis okiratokkal igazolják a termék tartalmát vagy eredetét. ${ }^{48}$

A kimutatások alapján megállapítható, hogy légi úton veszélyeztett hüllőket, korallokat és halakat csempésznek.

A veszélyeztett hüllőkkel való illegális nemzetközi kereskedelem vezető helyet foglal el a világon (ENSz Jelentés) A bőripar szabályozatlanságának köszönhetően évente több mint 10 millió veszélyeztetett hüllőt gyilkolnak le. A hüllők bőrével kereskedő vállalkozások előszeretettel hamisítják a hüllőbőr származási helyére vonatkozó iratokat, gyakran úgy teszik legálissá, hogy regisztrált farmokat jelölnek meg származási helyként. ${ }^{49}$

A magyarországi hüllőcsempészetben a NAV által végrehajtott lefoglalások számának jelentős hányadát alkotják a veszélyeztetett hüllők (kígyók, krokodilok, teknősök), illetve elsősorban azok származékai (például bőrük), illetve abból készített termékek. Krokodilbőrből vagy kígyóbőrből készült táskákat, öveket és más tárgyakat csempésznek jellemzően légi úton feladott poggyászban, míg élő görög teknősöket személygépkocsival, jellemzően a déli határon keresztül.

Az EU az egyik legfőbb korallimportőr a világon. Az importált korallokat elsősorban gyújtők vásárolják fel tengeri akváriumok kialakításához. A nemzetközi trendeknek megfelelően a veszélyeztetett fajnak számító korallok csempészete is előfordul hazánkban, jellemzően légi úton feladott poggyászban szállítják kisebb tételben, egzotikus országokból, így Indonéziából, Thaiföldről és a Fülöp-szigetekről. A csempészett áru mennyisége ritkán haladja meg a nagyobb tételt, vagyis hazánkba szakértői interjú szerint főleg turisták saját célokra hozzák be illegálisan, nagyrészt tudatlanságból, a szabályok nem kellő ismerete miatt.

Jelen tanulmány elkészítéséhez a már hivatkozott szakértői interjúkat a Nemzeti Adó- és Vámhivatal Repülőtéri Igazgatóság utas- és postaforgalmi szakterületének egyegy munkatársával készítettük, amelyek során az alábbiak hangzottak el.

A NAV munkatársai elmondták, hogy a repülőtéren az utasforgalomban idényjelleggel találkoznak veszélyeztett állat- vagy növényfajok illegális behozatalával. Ilyen eset, amikor nemzetközi orchideakiállítást rendeznek valahol a világon, megnövekszik a CITES-engedélyhez kötött orchidea illegális behozatala. Másik példa volt korábban, hogy amikor az üvegangolnák ívása történik Távol-Keleten, jellemzően megnövekszik az élő angolnák csempészete. Az ilyen nemzetközi jellegű eseményeket megelőzően a NAV értesítést kap a Központi Irányítástól arra vonatkozóan, hogy az eseménnyel kapcsolatban mely nemzetközi járatokon, milyen állat- vagy növényfaj csempészetére lehet számítani. A Központi Irányítás sokszor fényképeket is küld a könnyebb azonosítás érdekében. Jellemzően nagy a látenciája az ilyen típusú felederítéseknek. Az utóbbi években a postaés áruforgalomban kevesebb lefoglalás történt, mint az utasforgalomban.

\footnotetext{
48 Illicit Trafficking in Endangered Plant Species and Varietes (2019)

49 Liddick (2011)
} 
Az utasforgalomban jellemzően állatokat csempésznek, elsősorban tudatlan turisták hoznak be korallokat egzotikus országokból, kisebb-nagyobb mennyiségben, illetve egzotikus hüllők bőrét, ezenkívül veszélyeztett állati és növényi részt tartalmazó gyógyhatású készítményeket. A postaforgalomról elmondható, hogy az afrikai országokból állati eredetű, míg a Távol-Keletről növényi eredetű termékeket csempésznek.

$\mathrm{Az}$ utasforgalom esetében, amikor egy ember vagy egy csoport egzotikus vadász szafariról vagy egzotikus nyaralásról tér haza, a vámosok nagyobb kockázatként kezelik, és jellemzően alaposabb ellenőrzés alá vonják ezeket az utasokat, amelynek során elsősorban ilyen típusú árut keresnek. Ezenkívül jellemzően azokat az utasokat ellenőrzik általában, akik a vámosok azon kérdésére, hogy van-e vámköteles áru a birtokukban, feltűnően idegesen reagálnak, ilyenkor szúrópróbaszerű ellenőrzés alá vonják őket. Sajnálatosan az utóbbi években az utasforgalmi vámellenőrzésben a veszélyeztett fajok felderítésénél nagyobb hangsúlyt kapott a jövedéki termékek felderítése, mivel azok állami bevételt jelentenek. A postaforgalom esetében az ellenőrzéseket kockázatelemzések segítségével tervezik meg.

Az utasforgalomban általában olyan álcázási, elrejtési módszereket alkalmaznak, mint más illegális csempészek, ruházat alá rejtve, feladott poggyászban fehérnemúbe csavarva, elefántcsont ékszert más ékszerek közé rejtenek. Az interjúk során elhangzott egy érdekes példa is: egy Dél-Afrikából hazatérő magyar férfi 2 db frissen kifőzött majomkoponyát kívánt illegálisan behozni poggyászában Magyarországra, amelyeket feladott csomagjában lévő bakancsába helyezett. A koponyák kellemetlen szagot árasztottak, ezért a gyanús csomagot a NAV munkatársai ellenőrzésük alá vonták, amelynek során megtalálták a koponyákat, amelyek még nedvesek voltak.

Elhangzott továbbá, hogy a veszélyeztetett állat- vagy növényfajokból készült gyógyhatású termékek csempészetét megvalósító elkövetők jellemzően átcímkézett gyógyszeres dobozokba rejtik az árut, illetve üres üvegcsékbe tesznek ilyen tablettákat. A postaforgalomban kevésbé jellemző az álcázás.

Sem az utasforgalomban, sem a postaforgalomban nem jellemző hamis CITES-engedély bemutatása. Az viszont igen, hogy nagyobb mennyiséget csempésznek, mint amennyi az engedélyben szerepel, ez például orchidea esetében fordult elő többször. Ugyanígy nem jellemző egyik forgalomban sem, hogy más illegális áruval (például kábítószer vagy jövedéki termék) együtt csempésznek veszélyeztett állat- vagy növényfajt.

\section{Jogellenes szállítás a közúti személyforgalomban}

A NAV Központi Irányítás Rendészeti főosztály által készített adatok szerint a közúti határátkelőhelyeken elsősorban a CITES védettség alatt álló növényeket (hóvirágot, illetve a hazai védettség alatt álló havasi tőzikét és kárpáti sáfrányt) vágott formában és cserépben szállítják hazánkba vagy hazánkon keresztül, amely virágokat feltehetően a feketepiacon értékesítik. A szállítmányok elsősorban Ukrajnából érkeznek, ezt alátámasztja az a tény, hogy a NAV észak-alföldi régiójában foglaltak le nagyobb mennyiségben, összesen 99 millió 890 ezer Ft eszmei értékben. A NAV által készített kimu- 
tatásokból és egyes jelentésekből kiderül, hogy ezeket a virágokat csupán átszállítják Magyarországon és feltehetően Olaszországban és más nyugat-európai országokban értékesítik.

5. táblázat: A NAV Észak-alföldi régiójában lefoglalt védett növények (2014-2018). Forrás: NAV Központi Irányítása Vám Föosztály

\begin{tabular}{|c|c|c|c|c|}
\hline Év & Virágfajta & Védettség & Csempészett mennyiség & Eszmei érték \\
\hline 2014 & Hóvirág & CITES II. & 6752 szál & $67520000 \mathrm{Ft}$ \\
\hline 2015 & Hóvirág & CITES II. & 58 szál & $580000 \mathrm{Ft}$ \\
\hline 2015 & $\begin{array}{l}\text { Tavaszi } \\
\text { tôzike }\end{array}$ & 100/2012. (IX. 28.) VM rendelet & 132 szál & $660000 \mathrm{Ft}$ \\
\hline 2016 & Hóvirág & CITES II. & 3017 szál & $30170000 \mathrm{Ft}$ \\
\hline 2016 & $\begin{array}{l}\text { Kárpáti } \\
\text { sáfrány }\end{array}$ & $\begin{array}{l}\text { 13/2001. KöM rendelet } 1 . \mathrm{sz} \\
\text { melléklet }\end{array}$ & 96 szál & $960000 \mathrm{Ft}$ \\
\hline 2017 & Hóvirág & CITES II & 1319 szál & $1319000 \mathrm{Ft}$ \\
\hline
\end{tabular}

A közúti személyforgalomban hóvirágon kívül hazai jogszabályok védettsége alatt álló madarakat csempésznek részben az EU kelet- és közép-európai országaiból (Románia és Bulgária), részben harmadik országokból (Bosznia-Hercegovina, Szerbia) illegálisan, Nyugat- és Dél-Európába (Franciaország, Olaszország, Málta), elsősorban étkezési célokból..$^{50}$

A csempészett védett madarak jellemzően nem CITES-listán szereplő fajok, és nem minden esetben kapnak nemzetközi védettséget, olykor csak hazánkban vagy egyes tranzitországokban védettek, a forrásországokban nem. Jellemzően gépkocsival, élve vagy feldolgozva, fagyasztva szállítják az egyedeket (esetenként több százat vagy ezret) a célországokba, amiben hazánk a tranzitszerepet tölti be. ${ }^{51}$

A NAV által rendelkezésünkre bocsátott anyag szerint rendszerint kisbuszon vagy gépkocsin, rejtett módon (ülések alá rejtve) szállítják ezeket a madarakat (élve, kalitkában vagy feldolgozva, lefagyasztva). Sajátos elterelő módszer, hogy a csempész közli a vámhatóság tagjával, hogy van elvámolni való áru a birtokában: egy vagy két karton cigaretta, remélvén, hogy így a további vámvizsgálatot megkerülheti. Azonban a NAV munkatársa ennek ellenére végrehajtja a rutinvizsgálatot, amelynek során felfedezi az illegális árut.

\footnotetext{
Sina et al. (2016) 60.

1 Arih-Boljesic-Mavri (2008) 13.
} 
6. táblázat: A NAV Dél-alföldi-régiójában és mélységi ellenörzés során lefoglalt védett madarak (2014-2018). Forrás: NAV Központi Irányítás Rendészeti Föosztály

\begin{tabular}{|c|c|c|c|c|}
\hline Év & Madárfajta & Védettség & Csempészett mennyiség & Eszmei érték \\
\hline 2014 & Tengelic & $\begin{array}{l}\text { 13/2001. KöM rendelet 2. sz } \\
\text { melléklet }\end{array}$ & $\begin{array}{c}40 \text { példány } \\
\text { (élő) }\end{array}$ & $1000000 \mathrm{Ft}$ \\
\hline 2015 & $\begin{array}{c}\text { Kenderike } \\
\text { Tengelic } \\
\text { Fürj }\end{array}$ & $\begin{array}{l}\text { 13/2001. KöM rendelet 2. sz } \\
\text { melléklet }\end{array}$ & $\begin{array}{l}8 \text { példány } \\
18 \text { példány } \\
580 \text { példány }\end{array}$ & $\begin{array}{c}200000 \mathrm{Ft} \\
450000 \mathrm{Ft} \\
29000000 \mathrm{Ft}\end{array}$ \\
\hline 2016 & $\begin{array}{c}\text { Tengelic } \\
\text { (mélységi ellenőrzés) }\end{array}$ & $\begin{array}{l}\text { 13/2001. KöM rendelet 2. sz } \\
\text { melléklet }\end{array}$ & $\begin{array}{l}6 \text { példány } \\
950 \text { példány }\end{array}$ & $150000 \mathrm{Ft}$ \\
\hline 2017 & $\begin{array}{c}\text { Tengelic } \\
? \\
\end{array}$ & $\begin{array}{l}\text { 13/2001. KöM rendelet 2. sz } \\
\text { melléklet } \\
\end{array}$ & $\begin{array}{l}10 \text { példány } \\
2953 \text { példány }\end{array}$ & $\begin{array}{c}250000 \mathrm{Ft} \\
?\end{array}$ \\
\hline 2018 & $\begin{array}{c}\text { Barázdabillegető } \\
90 \text { db rétipityer mezei } \\
\text { pacsirta (mélységi ellen- } \\
\text { őrzés) }\end{array}$ & $\begin{array}{l}\text { 13/2001. KöM rendelet } 2 . \text { sz } \\
\text { melléklet }\end{array}$ & $\begin{array}{l}333 \text { példány } \\
90 \text { példány } \\
1805 \text { példány }\end{array}$ & $\begin{array}{c}825000 \mathrm{Ft} \\
2250000 \mathrm{Ft} \\
45125000 \mathrm{Ft}\end{array}$ \\
\hline
\end{tabular}

\section{Felvetések, megoldási lehetőségek}

A veszélyeztetett fajok kereskedelmének ellenőrzése, a visszaélések megakadályozása és a kockázatok minimalizálása az engedélyezésben és az ellenőrzésben érintett hatóságok közti szorosabb együttmúködés révén valósulhat meg. Ehhez megfelelő alapot teremt a Korm. rendelet, amely a szabálytalan szállítás esetében az értesítés és tájékoztatás rendjét határozza meg a hatóságok számára. A NAV 2011-es létrejötte előtt a Vám- és Pénzügyőrség (mint a NAV egyik jogelődje), illetve a Vidékfejlesztési Minisztérium (mint az AM jogelődje) közt volt együttmüködési megállapodás, amely tartalmazta a veszélyeztetett fajok forgalmának felügyeletét érintő közös hatósági feladatokat. A jogelőd szervezetek által kötött megállapodások azonban hatályukat vesztették, jelenleg a NAV és az AM között nincs olyan hatályos együttmúködési megállapodás, amely a témakört érintő közös feladatokat rendezné. A veszélyeztetett fajok illegális kereskedelmének visszaszorítását célzó együttműködés részletes szabályait szükséges lenne együttmúködési megállapodásban rögzíteni a NAV és az AM (mint CITES igazgatási hatóság) között.

A témakörben a NAV nagy hangsúlyt fektet állománya képzésére. Az elmúlt években rendszeres képzésekre került sor a veszélyeztetett fajok vámhatósági ellenőrzését illetően a Nemzeti Közszolgálati Egyetem Rendészettudományi Karának, illetve a NAV Képzési, Egészségügyi és Kulturális Intézet Pénzügyőri Iskolájának pénzügyőr hallgatói számára. A képzéseket a jövőben is folytatni szükséges, azonban a képzési programba indokolt valamennyi ellenőrzésben érintett társhatóságot (elsősorban az AM-et) is bevonni. Szintén fontos a környezettudatosság erősítése és a közvélemény (kiemelten a fiatalok) tájékoztatása a változatos élővilág fennmaradását veszélyeztető körülményekről. Ezért a NAV rendszeres részvétele is elengedhetetlen a vadvilágot érintő rendezvényeken (például a témakört érintő kiállításokon, fesztiválokon, iskolákban). 


\section{Összegzés}

Az EU nemzetközi kereskedelmének felügyeletét biztosító uniós vámhatóságok szerepe mára átértékelődött. A vámhatóságok már nem csupán a tagállamok és az EU költségvetését biztosítják, hanem - az UVK 3. cikk c) pontjában lefektetett elvek (a vámhatóság küldetése) mentén - közremüködnek környezetünk védelme érdekében, és e tevékenységük során együttmúködnek más hatóságokkal. Az elmúlt évtizedeket értékelve mindenképpen kijelenthetjük, hogy a Föld élővilága védelemre szorul, amely többek között a veszélyeztetett fajok kereskedelmének összehangolt hatósági ellenőrzésével biztosítható. A legális szállítások ellenőrzésének megfelelő színvonalú elvégzéséhez korszerúsíteni szükséges az eddigiekben alkalmazott felügyeleti, vizsgálati módszereket. A megfelelő hatósági felügyelet és egyúttal a változatos élővilág fennmaradásának biztosításához elengedhetetlen a hatóságok, a CITES-engedélyesek és a környezetvédelemmel foglalkozó civil szervezetek közti szorosabb partneri viszony kialakítása, a gyakorlati tapasztalatok kölcsönös megosztása. A veszélyeztetett fajok szállításának ellenőrzésére vonatkozó rendelkezéseket úgy kell kialakítani, hogy az intézkedések ne hátráltassák a jogszerű kereskedelmet. Az ellenőrzésekben érintett hatóságok célja tehát nem lehet más a jövőben, mint a gazdálkodók és a magánszemélyek beterelése a veszélyeztetett fajok legális kereskedelmének folyamataiba.

A veszélyeztett állat- és növényfajok illegális kereskedelme határokon átívelő globális jelenséggé vált a 21. századra. Az illegális szállítás a gazdaságilag gyengébb, természeti kincsekben erősebb célországokból a gazdaságilag erősebb és gyengébb természeti erőforrásokkal rendelkező célországok felé történik. Az esetek egy részében egy vagy esetleg két elkövető jelenik meg (eladó-vevő) ebben a tevékenységben, jellemzően azon esetekben, amikor turisták saját céljaikra szállítanak veszélyeztett állatokat vagy növényeket. Azonban azok az esetek, amelyeknél a vámhatóság nagyobb tételben derít fel és foglal le ilyen típusú árut, feltehetően nemzetközi hálózatok tevékenységére bukkantak. Az ilyen esetekben hosszú láncolatok alakultak ki a forrástól a tranzitállomásokon keresztül egészen a célországokig, amely láncolat egyes résztvevői: orvvadászok, csempészek, közvetítők, kereskedők, mely tevékenységnek a magyarországi vámhatósági ellenőrzés csupán egy állomásával, egy szereplőjével - a csempész - találkozik.

Ugyanakkor az is kijelenthető, hogy bár az Európai Unió egyes országai komoly felvevő piacnak számítanak a veszélyeztetett állat- vagy növényfajok illegális kereskedelmében, hazánk a jelenlegi adatok szerint nem tölt be központi szerepet, és leginkább a tranzitforgalom tekintetében érintett. Nem elhanyagolható, hogy a veszélyeztett állat- és növényfajok illegális nemzetközi kereskedelmével foglalkozó egyes nemzetközi kutatások szerint e tevékenységben óriási a látencia, egyes adatok szerint például a lefoglalások száma az összes illegálisan csempészett állatok vagy növények csupán 10\%-át teszik ki. ${ }^{52}$ Ezt a tényt e cikk készítésekor elhangzott szakértői interjúk is megerősítik, azaz a vámhatóságok csupán a jéghegy csúcsával találkoznak.

52 Stiles et al. (2013) 8. 
A látencia tényére tekintettel mindenképpen fokozni kell a rendőri és vámhatósági eredményes felderítések számát, amelyhez a felderítési módszerek hatékonyságát is fejleszteni kell. A felderítések hatékonyságát az új büntetőeljárási törvény felderítési rendszere is támogatja, mivel a titkos információgyüjtés és a titkos adatszerzés különleges eszközeinek és módszereinek eredménye a továbbiakban a bizonyítási eszközök és cselekmények katalógusát gazdagíthatják. ${ }^{53}$ Ezzel a felderítés eredménye közvetlenül felhasználhatóvá válik a büntetőeljárásban.

Ugyanakkor kijelenthető, hogy a megoldást nem csupán a vámhatósági vagy rendőrségi eredményes felderítések növelése adhatja, mivel a jelenség jóval túlmutat a csempészek tevékenységén, több társadalmi probléma által jött létre. Mint minden illegális termékkereskedelemben, így ebben is jellemzően a keresleti oldalon kellene az okokat megismerni, megszüntetni, például megfelelő oktatással, propagandával. ${ }^{54}$

Jelen cikk végén álljon egy idézet Őszentségétől, a XIV. Dalai Lámától (Tendzin Gjaco), amely a természetvédelem alapgondolata is egyben: „Minden élőlény, a rovaroktól kezdve, boldogulni akar, nem szenvedni. Az ember csak egy a végtelen számú többi élőlény között. Ezért kétségtelen, hogy nem lehet fontosabb az ő boldogulása az összes többinél, főleg nem azok kárára."

\section{IRODALOMJEGYZÉK}

Arih, Andrej - Bolješič, Robert - Mavri, Urška - Vaupotič, Marjan - Lengar, Tinka (2008): Report on the attempts of smuggling of wild birds into the Republic of Slovenia (2002-2006). Ljubjana, Environment Agency of the Republic of Slovenia.

Gyulai Iván (2011): A fenntartható fejlődés. A világ helyzete a fenntarthatóság szempontjából, Tananyag döntéshozók számára: II. rész. Magyar Természetvédők Szövetsége, Föld Barátai Magyarország. Forrás: https://mtvsz.hu/dynamic/fenntart/ff_avilaghelyzete.pdf (2019. 09. 16.)

Liddick, Don R. (2011): Crimes against nature. Illegal industries and the global environment. UK, Oxford Praeger Publishers.

Marosi Katalin (2015): Alig felére csökkent a vadon élő állatok száma. Magyar Nemzet, 2015. április 26. Forrás: https://magyarnemzet.hu/archivum/tudomany-es-technika/alig-felere-csokkenta-vadon-elo-allatok-szama-4040110/ (2019. 09. 28.)

Nyeste Péter (2017): A leplezett eszközök hatékonysága. In Gaál Gyula - Hautzinger Zoltán szerk.: Szent Lászlótól a modernkori magyar rendészettudományig. Pécs, Pécsi Határőr Tudományos Közlemények XIX. kötet.

Nyeste Péter (2019): A nyugat-európai szervezett bünözés jellemzői. In Szendrei Ferenc szerk.: A nemzetközi és honos szervezett bünözés története, a XX. századi fejlödése és várható tendenciái. Budapest, Dialóg Campus Kiadó. 41-53.

Razaque, Abdul - Kejun, Du - Xueqi, Zhu - Wanyue, Li - Hani, Qassim Bani - Khan, Meer Jaro (2018): Survey: Wildlife trade and related activities over the internet. IEEE Long Island Systems, Applications and Technology Conference (LISAT). DOI: https://doi.org/10.1109/LISAT.2018.8378037

Suba László - Szendi Antal (2018): Az uniós vámjog vázlata. Budapest, Dialóg Campus Kiadó.

\footnotetext{
$53 \quad$ Nyeste (2017) 157.

$54 \quad$ Razaque et al. (2018) 7.
} 
Stiles, Daniel - Redmond, Ian - Cress, Doug - Nellemann, Christian - Formo, Rannvieg Knutsdatter (2013): Stolen Apes - The Illicit Trade in Chimpanzees, Gorillas, Bonobos and Orangutans. A Rapid Response Assessment, United Nations Environment Programme.

Sina, Stephen - Gerstetter, Christiane - Porsch, Lucas - Roberts, Ennid - Smith, Lucy O. - Klaas, Katharina - de Castillo, Teresa Fajardo (2016): Wildlife Crime. Directorate General for Internal Policies, European Parliament.

Sziebig Orsolya Johanna (2019): A vadvilági bünözés elleni küzdelem jogi eszközei. Doktori értekezés. Szeged, Szegedi Tudományegyetem Állam- és Jogtudományi Doktori Iskola. Forrás: www. juris.u-szeged.hu/karunkrol/tudomanyos-archivum/tudomanyos-archivum (2019. 09. 28.)

Sziebig Orsolya Johanna (2018): A veszélyeztetett fajok kereskedelmének uniós szabályozása: a CITES szabályainak végrehajtása az Európai Unióban. Miskolci Jogi Szemle, 13. évf. 2. sz. 119-132. https://www.mjsz.uni-miskolc.hu/files/egyeb/mjsz/20180202/10_sziebigorsolya.pdf (2019. 09. 25.)

Tilki Katalin (2004): Környezetkárosítás és természetkárosítás: a környezetvédelem aktuális problémái. Magyar Rendészet, 4. évf. 2. sz. 79-108.

TRAFFIC, Overview of Important International Seizures of CITES-Listed Specimens in the European Union (2013). January to December 2012, European Commission.

Uhm, Daan P. van (2016): The illegal wildlife trade, Inside the World of poachers, smugglers and traders. Switzerland, Springer Internatonal Publishing AG.

World wildlife crime report, Trafficking in protected species (2016). Vienna - New York, United Nation Office on Drugs and Crime. Forrás: www.unodc.org/documents/data-and-analysis/wildlife/ World_Wildlife_Crime_Report_2016_final.pdf (2019. 09. 25.)

Zsigmond Csaba (2018): A környezeti büncselekmények és a szervezett bűnözés. In Frigyer László szerk.: Nemzetközi jellegú szervezett bünözés kutatása információáramlási szempontból, Tanulmánykötet 1. Budapest, Nemzeti Közszolgálati Egyetem.

\section{Jogforrások}

1007/2009/EK európai parlamenti és tanácsi rendelet a fókatermékek kereskedelméről

13/2001. (V. 9.) KöM rendelet a védett és a fokozottan védett növény- és állatfajokról, a fokozottan védett barlangok köréröl, valamint az Európai Közösségben természetvédelmi szempontból jelentős növény- és állatfajok közzétételéről

1995. évi LXXXI. törvény a Biológiai Sokféleség Egyezmény kihirdetéséről

1996. évi LIII. törvény a természet védelméről

2003. évi XXXII. törvény a Washingtonban, 1973. március 3. napján elfogadott, a veszélyeztetett vadon élő állat- és növényfajok nemzetközi kereskedelméről szóló egyezmény kihirdetéséről

2012. évi C. törvény a Büntető Törvénykönyvről

2017. évi CLII. törvény az uniós vámjog végrehajtásáról

2019/1587 bizottsági végrehajtási rendelet az egyes vadon élő állat- és növényfajok példányai unióba történő behozatalának a tanácsi rendeletben foglaltak szerinti tilalmáról

2019/1715 bizottsági végrehajtási rendelet (a hatósági ellenőrzések információkezelési rendszeréről szóló rendelet) a hatósági ellenőrzések információkezelési rendszerének és a rendszer elemeinek múködésére vonatkozó szabályok megállapításáról

2017/625 európai parlamenti és tanácsi rendelet (a hatósági ellenőrzésekről szóló rendelet) az élelmiszer- és takarmányjog, valamint az állategészségügyi és állatjóléti szabályok, a növényegészségügyi szabályok, és a növényvédő szerekre vonatkozó szabályok alkalmazásának biztosítása céljából végzett hatósági ellenőrzésekről és más hatósági tevékenységekről, továbbá a 999/2001/EK, a 396/2005/EK, az 1069/2009/EK, az 1107/2009/EK, az 1151/2012/EU, a 652/2014/EU, az (EU) 2016/429 és az (EU) 2016/2031 európai parlamenti és tanácsi rendelet, az 1/2005/EK és az 1099/2009/EK tanácsi rendelet, valamint a 98/58/EK, az 1999/74/EK, 
a 2007/43/EK, a 2008/119/EK és a 2008/120/EK tanácsi irányelv módosításáról, és a 854/2004/ EK és a 882/2004/EK európai parlamenti és tanácsi rendelet, a 89/608/EGK, a 89/662/ EGK, a 90/425/EGK, a 91/496/EGK, a 96/23/EK, a 96/93/EK és a 97/78/EK tanácsi irányelv és a 92/438/EGK tanácsi határozat hatályon kívül helyezéséről

2016/2031 európai parlamenti és tanácsi rendelet a növénykárosítókkal szembeni védekező intézkedésekről, a 228/2013/EU, a 652/2014/EU és az 1143/2014/EU európai parlamenti és tanácsi rendelet módosításáról, valamint a 69/464/EGK, a 74/647/EGK, a 93/85/EGK, a 98/57/EK, a 2000/29/EK, a 2006/91/EK és a 2007/33/EK tanácsi irányelv hatályon kívül helyezéséről

28/2015. (VI. 17.) OGY határozat a biológiai sokféleség megőrzésének 2015-2020 közötti időszakra szóló nemzeti stratégiájáról

292/2008. (XII. 10.) Korm. rendelet a veszélyeztetett vadon élő állat- és növényfajok nemzetközi kereskedelmét szabályozó nemzetközi és európai közösségi jogi aktusok végrehajtásának egyes szabályairól

338/97/EK tanácsi rendelet a vadon élő állat- és növényfajok számára kereskedelmük szabályozása által biztosított védelemről

71/2015. (III. 30.) Korm. rendelet a környezetvédelmi és természetvédelmi hatósági és igazgatási feladatokat ellátó szervek kijelöléséről

865/2006/EK bizottsági rendelet a vadon élő állat- és növényfajok számára kereskedelmük szabályozása által biztosított védelemről szóló 338/97/EK tanácsi rendelet végrehajtására vonatkozó részletes szabályok megállapításáról

93/444/EGK bizottsági határozat a harmadik országokba való kivitelre szánt egyes élő állatok és termékek Közösségen belüli kereskedelmére vonatkozó részletes szabályokról

952/2013/EU európai parlamenti és tanácsi rendelet az Uniós Vámkódex létrehozásáról

A Bizottság jelentése az Európai Parlamentnek, az Európai Tanácsnak, és a Tanácsnak Hatodik eredményjelentés a hatékony és valódi biztonsági unió megvalósításáról (2017). Brüsszel, Európai Bizottság. COM(2017)213 final. Forrás: https://eur-lex.europa.eu/legal-content/HU/TXT/PDF /?uri=CELEX:52017DC0213\&from=EN (2019. 09. 30.)

A Bizottság közleménye az Európai Parlamentnek, a Tanácsnak, az Európai Gazdasági és Szociális Bizottságnak és a Régiók Bizottságának. A vadon élő állatok és növények jogellenes kereskedelme elleni uniós cselekvési terv (2016). Brüsszel, Európai Bizottság. COM(2016) 87 final. Forrás: https://eur-lex.europa.eu/legal-content/HU/TXT/?uri=CELEX\%3A52016DC0087 (2019. 09. 27.)

A Rio de Janeiróban 1992. június 13-án aláírt Biológiai Sokféleség Egyezmény

A vadon élő állat- és növényfajok számára kereskedelmük szabályozása által biztosított védelemről szóló 338/97/EK tanácsi rendelet végrehajtását segítő intézkedésekről szóló 2007/425/EK bizottsági ajánlás (2007). Európai Bizottság. Forrás: https://eur-lex.europa.eu/legal-content/HU/ TXT/?uri=CELEX\%3A32007H0425 (2019. 09. 26.)

A vadon élő állatokat és növényeket érintő büncselekmények elleni küzdelem, az Európai Parlament 2014. január 15-i állásfoglalása a vadon élő növényekkel és állatokkal kapcsolatos büncselekményekről (2014). Európai Parlament [2013/2747 (RSP)], C 482/83. Forrás: http://www.europarl. europa.eu/sides/getDoc.do?pubRef=-//EP//TEXT+TA+P7-TA-2014-0031+0+DOC+XML+V0// HU (2019. 09. 26.)

A Washingtonban, 1973. március 3. napján elfogadott, a veszélyeztetett vadon élő állat- és növényfajok nemzetközi kereskedelméről szóló egyezmény

Életbiztosításunk, természeti tókénk: a biológiai sokféleséggel kapcsolatos, 2020-ig teljesítendő uniós stratégia, A Bizottság közleménye az Európai Parlamentnek, a Tanácsnak, a Gazdasági és Szociális Bizottságnak és a Régiók Bizottságának (2011). Brüsszel, Európai Bizottság 2011. május 3., COM (2011). Forrás: https://eur-lex.europa.eu/legal-content/HU/TXT/?uri=CELEX\%3A52011DC0244 (2019. 09. 26.)

Illicit Trafficking in Endangered Plant Species and Varietes (2019). Europol. Forrás: www.europol.europa.eu/crime-areas-and-trends/crime-areas/environmental-crime/illicit-trafficking-in-endangered-plant-species-and-varieties (2019. 10. 28.)

Magyarország Alaptörvénye 


\section{Internetes források}

Bodnár Zsolt (2019): Szinte mindenhol tiltják, mégis virágzik a kereskedelem a veszélyeztetett állatok csontjaival. Forrás: https://qubit.hu/2019/05/20/szinte-mindenhol-tiltjak-megis-viragzik-a-veszelyeztetett-allatok-csontjaival-valo-kereskedes (2019. 09. 28.)

Maqbool, Raihana (2015): Smuggling Threatens Survival of Medicinal Plants in Kashmir but Provides Income for Poor Villagers. Global Press Journal, 2015. 11. 08. Forrás: https://globalpressjournal. com/asia/indian-administered_kashmir/smuggling-threatens-survival-of-medicinal-plants-inkashmir-but-provides-income-for-poor-villagers/ (2019. 10. 28.)

\section{ABSTRACT}

\section{The Customs Control of the Trade of Endangered Wild Species}

HARNBERGER György - ZSIGMOND Csaba

Several thousand species have become endangered for the last few decades owing to legal and illegal trading; nonetheless the authorities and the public opinion do not pay proper attention to this issue. In this paper the authors examined the specifics of legal and illegal trading, the legal background and the theoretical background of customs control and the practical experiences. They give an overview of the international and national laws, the international literature and the international trends. They analysed in their research the seizure dates of the Hungarian National Tax and Customs Administration, and interviewed two customs officers in order to know specifics of the illegal trading. According to their research, our country does not play a central role in illegal trading, nevertheless the value of the illegal market reaches several million Forints. Hungary is mainly a transit country, and the illegal market is conducted especially by air. According to the seizure dates, in most of the cases the smugglers play for high stakes, and they most probably belong to international criminal networks and organised groups. Based on this article and research we can say that this issue should be paid more attention to, and not only successful detections by law emforcement can reduce illegal market, but social attention is also needed.

Keywords: customs control, legal, illegal, permit, CITES, endangered species, wildlife trafficking, environment crime 